\title{
Florida's Property Tax Reform: Proposed Constitutional Changes ${ }^{1}$
}

Rodney L. Clouser ${ }^{2}$

\section{Introduction}

In June 2007, during a special legislative session, the Florida Legislature made changes in the state's property tax system. The legislature adopted both statutory changes and a proposed constitutional amendment. These changes were signed into law by the Governor on June 21, 2007. However, the proposed constitutional amendment was ruled unconstitutional by a circuit court judge in September, who found the ballot summary proposed by the legislature to be "misleading and inaccurate and shall not be placed on the ballot for a special election scheduled January 29, 2008".

The legislature then reconvened in October, their fourth special session this year, to address property tax issues as a result of the court ruling. A new plan was developed and approved on October 29-30, 2007, and this legislation becomes the basis for a proposed constitutional amendment that will be voted on by Florida residents on January 29, 2008.
The proposed constitutional changes made during the October 2007 special legislative session are discussed in this factsheet. These changes will be voted on by electors at the same time as the state's presidential primaries. The proposed amendment has four core components: exemption of tangible personal property, doubling the homestead tax exemption; portability of the Save Our Homes (SOH) differential statewide; and a ten percent cap on the increase in assessments of non-homestead property. This factsheet is organized around those topics.

\section{Proposed Constitutional Changes}

\section{The Special Election}

The simplest part of the action taken by the Florida Legislature during the October 2007 special session was the call for the vote on the constitutional amendment (SB 6D, enrolled). The vote is required to take place on January 29, 2008 and be consistent with Article XI, Section 5 of the Florida Constitution. A sum of $\$ 560,000$ was appropriated from nonrecurring

1. This is EDIS document FE705, a publication of the Food and Resource Economics Department, Florida Cooperative Extension Service, Institute of Food and Agricultural Sciences, University of Florida, Gainesville, FL. This document is part of a series of documents on Florida Property Tax Reform. Published December 2007. Please visit the EDIS website at http://edis.ifas.ufl.edu.

This factsheet should not be considered as a comprehensive assessment of property tax changes adopted or proposed by the legislature. Some details of actual or proposed changes are not discussed due to space limitations. This factsheet represents the interpretation by the author(s) of the most significant changes. This factsheet is not intended as a replacement for personal knowledge about actual or proposed changes but is a guide to inform the public on property tax issues.

2. Rodney L. Clouser, Professor and Extension Public Policy Specialist, Food and Resource Economics Department, Florida Cooperative Extension Service, Institute of Food and Agricultural Sciences, University of Florida, Gainesville, FL.

The Institute of Food and Agricultural Sciences (IFAS) is an Equal Opportunity Institution authorized to provide research, educational information and other services only to individuals and institutions that function with non-discrimination with respect to race, creed, color, religion, age, disability, sex, sexual orientation, marital status, national origin, political opinions or affiliations. U.S. Department of Agriculture, Cooperative Extension Service, University of Florida, IFAS, Florida A. \& M. University Cooperative Extension Program, and Boards of County Commissioners Cooperating. Larry Arrington, Dean 
general revenue funds to advertise the amendments being put forward by the legislature to the voters of the state.

\section{Tangible Personal Property}

The proposed constitutional amendments cover several different topics (Senate Joint Resolution (SJR) 2D and SB4D). One topic is an exemption of $\$ 25,000$ of the assessed value of property subject to tangible personal property tax. Tangible personal property is defined in Florida Statute 192.001 (11) (d) as: "Tangible personal property" means all goods, chattels, and other articles of value (but does not include the vehicular items enumerated in $\S 1(b)$, Art. VII of the State Constitution and elsewhere defined) capable of manual possession and whose chief value is intrinsic to the article itself. "Construction work in progress" consists of those items of tangible personal property commonly known as fixtures, machinery, and equipment when in the process of being installed in new or expanded improvements to real property and whose value is materially enhanced upon connection or use with a preexisting, taxable, operational system or facility. Construction work in progress shall be deemed substantially completed when connected with the preexisting, taxable, operational system or facility. Inventory and household goods are expressly excluded from this definition.

And further defined in Florida Statute 212.02 (19) as:

\section{"(19)personal property" means and includes personal property which may be seen, weighed, measured, or touched or is in any manner perceptible to the senses, including electric power or energy, boats, motor vehicles and mobile homes as defined in $\$ 320.01(1)$ and (2), aircraft as defined in $\$ 330.27$, and all other types of vehicles. The term "tangible personal property" does not include stocks, bonds, notes, insurance, or other obligations or securities or pari-mutuel tickets sold or issued under the racing laws of the state".}

The Florida Constitution, however, also exempts certain items from tangible personal property in Article VII, Section 1(b), Section 3(b and d) and
Section 4(b). If there are any questions regarding these exemptions, refer to the Florida Constitution.

In lay terms, "Tangible Personal Property Tax is an ad valorem tax assessed against (1) any equipment, fixtures, or furniture used in a business or for a commercial purpose; (2) leased equipment; (3) furnishings and appliances in a rental property, owned by the real property owner; and (4) any attachments made to a mobile home or manufactured housing in a rental park (Broward County Property Appraiser)," or "Tangible Personal Property is all property other than real estate that has value in and of itself. It includes items such as business machinery, industrial and farm equipment, tools and supplies, signs and leasehold equipment, and a variety of other types of property (Bradford County Property Appraiser)."

Therefore, all tangible personal property as defined in the Florida Statutes and not excluded by Florida Constitution, Article 7, Sections 1, 3, and 4 are impacted by this proposed amendment. The legislation explicitly states that the tangible personal property tax exemption does not apply to mobile homes. The exemption of $\$ 25,000$ in tangible personal property applies to levies of all government units including school levies (taxes).

\section{Homestead Exemption Increase from $\$ 25,000$ to $\$ 50,000$}

The proposed constitutional amendment would increase the current homestead tax exemption from $\$ 25,000$ to $\$ 50,000$. The increase, however, would only apply to homesteads with an assessed value greater than $\$ 50,000$. The way the increased homestead exemption is structured is that the exemption would apply to the first $\$ 25,000$ of assessed value, taxes would be paid on the next $\$ 25,000$ of value (assessed value between $\$ 25,000$ and $\$ 50,000$ ), and the remainder of the exemption $(\$ 25,000)$ would be applied to the assessed value over $\$ 50,000$, up to $\$ 75,000$ in assessed value. There are other relevant points associated with this proposed change, including that the increased exemption does not apply to school tax levies, homeowners with property assessed below $\$ 50,000$ will receive no additional homestead tax exemption and the changes retroactively become effective 
January 1, 2008 if approved by the voters on January 29, 2008.

\section{Portability}

Portability is best defined as the transferability of the difference between your property's just (market) value and the property's assessed value to a different property. This difference is important and may be large because of Florida's Save Our Homes (SOH) program. The proposed constitutional amendment allows for statewide portability. Individual homestead owners who had a homestead exemption and sold their homestead on or after January 1, 2007 are "grandfathered" into the proposed change as long as they apply for (have purchased) a new homestead no later than January 1, 2009. Portability benefits are transferable by homestead property owners on January 1, 2009 or January 1st of any year thereafter for individuals who have sold their home and had a homestead exemption in either of the two years prior to the establishment of the new homestead. The maximum dollar amount for portability is $\$ 500,000$ for those individuals whose purchase of a new homestead has a just value greater than the homestead that was sold. Therefore, the $\$ 500,000$ is a cap on portability. However, individuals who purchase a new homestead with a just value less than the prior homestead sold will also benefit from portability but on a proportional basis. If the just value of the new property is less than the just value of the prior property sold, the portability value is calculated by dividing the just value of the new property by the just value of the property sold. This percentage is then multiplied by the assessed value of the prior (sold) homestead. If the difference in the just value of the new homestead and the assessed value of the new homestead is greater than $\$ 500,000$, the assessed value will be adjusted so that the difference is $\$ 500,000$.

The portability provision applies to all units of local government taxation, including school districts. In addition, the proposal includes two other provisions. If two or more individuals who have each received a homestead exemption in the prior two years are eligible for a new homestead exemption, the reduction in just value is limited to the highest difference ( $\mathrm{SOH}$ differential) of the individuals but limited to $\$ 500,000$. This provision, for example, would cover two single individuals who both had homesteaded property and then married. Likewise, if two or more individuals have abandoned jointly owned property and a new homestead is established, each person is allowed a reduction in just value equal to the difference between the just value of the prior homestead and the assessed value of the new homestead, divided by the number of owners of the prior homestead. This differential is also limited to $\$ 500,000$ total for all the homesteads established under this condition. This provision, for example, would cover married individuals who had homesteaded property and then divorced.

\section{Non-Homestead Assessment Cap}

A non-homestead eligible property assessment cap is another component of the proposed amendment. The non-homestead cap is similar to the $\mathrm{SOH}$ limitation but the cap for non-homesteads is established at 10 percent, rather than the 3 percent cap established for homesteads. The 10 percent assessment cap for non-homestead property does not apply to school district levies. In addition, non-homestead residential property is defined as residential property containing nine or fewer units (i.e., no large apartment units with greater than nine units). In general, residential property will be reassessed when the property is sold. Residential property with 10 or more units and commercial property will be reassessed after a sale or significant improvements are made (just value increase of 25 percent or greater). Otherwise, assessed value will increase no more than 10 percent from year to year. Another aspect of this proposed change is that the non-homestead cap is repealed effective January 1, 2019 unless re-approved by the states voters (SJR 2-D). These proposed changes do not become effective until the 2009 tax year.

\section{Implementing Language: Fiscally Constrained Counties}

Although not a component of the constitutional amendment, beginning in the 2008-09 state fiscal year, SB 4-D authorizes the legislative appropriation of money to offset reductions in ad valorem tax collections for fiscally constrained counties. Fiscally constrained counties are defined as: 
Florida Statutes 218.67 (1)county that is entirely within a rural area of critical economic concern as designated by the Governor pursuant to $\$ 288.0656$ or each county for which the value of a mill will raise no more than $\$ 5$ million in revenue, based on the taxable value certified pursuant to $\S$ 1011.62(4)(a)1.a., from the previous July 1, shall be considered a fiscally constrained county.

Fiscally constrained counties can then apply to the Governor's office to participate in the distribution of legislatively appropriated money. The money will be distributed based on the county's proportion of the total statewide reduction in ad valorem taxes that results from approval of the constitutional amendment. The language does not appear to guarantee dollar for dollar replacement of lost revenue for fiscally constrained counties nor does it identify the source of money that will be appropriated to replace lost property tax revenue.

\section{Fiscal Impacts}

The estimated fiscal impacts of the proposed constitutional amendment based on Florida Senate estimates are:

- Fiscal Year 2008-09

- Non-school ..... (\$1.17 billion)

- School (\$204 million)

- Total ( $\$ 1.37$ billion $)$

- Fiscal Year 2009-10

- Non-school ..... (\$1.5 billion)

- School (\$387 million)

- Total ( $\$ 1.88$ billion $)$

- Fiscal Year 2010-11

• Non-school ..... (\$1.88 billion)

- School ............ (\$547 million)

• Total ............... ( $\$ 2.43$ billion $)$
- Fiscal Year 2011-12

- Non-school ..... (\$2.34 billion)

- School ............ (\$721 million)

• Total .............. (\$3.06 billion)

- Fiscal Year 2012-13

• Non-school ..... (\$2.74 billion)

- School ............ (\$898 million)

• Total ............... (\$3.64 billion)

- 5 Year Total

• Non-school ..... (\$9.62 billion)

- School ............ (\$2.76 billion)

- Total .............. (\$12.38 billion)*

(* New economic impact estimates of the proposed constitutional amendment were released by the state on December 18, 2007, and are reported in FE707.)

This is in addition to the $\$ 15.7$ billion estimated revenue impact resulting from statutory changes that took effect beginning in 2007-08. Remember, total ad valorem tax collections for all units of government, including schools, were approximately $\$ 30.4$ billion in fiscal year 2006. Over the five-year period, the combination of statutory and proposed constitutional changes would result in tax levies being $\$ 28$ billion less than if no changes were made by the legislature. This amount is slightly less than all ad valorem taxes collected in fiscal year 2006.

Remember, the statutory changes made by the legislature did not apply to schools (schools were "held harmless" from the statutory changes). That is not the case with the proposed constitutional changes. It is estimated that 23 percent of the dollar impact with the constitutional change ( $\$ 2.76$ billion over a five-year period beginning in 2008-09) will result from reduced public school revenues. In other words, schools are not "held harmless" from a revenue perspective with the proposed constitutional changes. It may be unlikely that school funding will 
actually decrease. The expected reduction in revenues may be covered by shifting state allocations from other departments and agencies, or identifying new revenue sources that would partially or completely replace the anticipated reductions in property tax funds for public education.

\section{Summary and Conclusion}

The proposed constitutional amendment if passed has multiple impacts and the magnitude of these impacts is difficult to assess. What we do know:

- The homestead exemption will increase from $\$ 25,000$ to $\$ 50,000$ for many property owners.

- Non-homestead property will see a cap on the annual increase in assessed value of 10 percent.

- Statewide portability will allow the $\mathrm{SOH}$ differential to be transferred from a prior home to a new homesteaded property with a maximum transfer of $\$ 500,000$.

- The exemption of $\$ 25,000$ of tangible personal property will result in lower taxes for those with tangible personal property but the decrease may be relatively small.

- Public education is not "held harmless" under the proposed constitutional amendment and school revenues will decline due to the decrease in property taxes unless funding to other state agencies and programs is shifted to education or new revenue sources are initiated.

- The total reduction in taxes anticipated from passage of the constitutional amendment is estimated to be just over $\$ 12$ billion between 2008-09 and 2012-13.

- Long term there is no guarantee that total payments (taxes, fees and assessments) for government services will decline.

Floridians will have a critical choice to make when they vote on the proposed constitutional changes on January 29, 2008. It is essential they become as informed as possible about what they are voting on so they can make an informed choice.

\section{References}

Bradford County Property Appraiser. 2007. Tangible Personal Property. http://www.bradfordappraiser.com/Tangible_Tax.asp . Visited website November 2007.

Broward County Property Appraiser. 2007. Tangible Personal Property Tax. http://www.co.broward.fl.us/revenue/rvi00313.htm. Visited website August 2007.

Florida Senate. 2007. 2007-D Special Session Summary of Legislation Passed. http://www.flsenate.gov/Publications/2007D/Senate/ reports/summaries/pdf/sessum07D.pdf. Visited website November 2007.

Florida Senate. 2007. The Florida Senate Professional Staff Analysis and Economic Impact Statement.

http://www.flsenate.gov/Publications/2007D/Senate/ reports/summaries/pdf/sessum07D.pdf. Visited website November 2007.

Florida Senate. 2007. Senate Joint Resolution 2-D, Enrolled. http://www.flsenate.gov/cgi-bin/ view_page.pl?Tab=session $\&$ Submenu $=1 \& \mathrm{FT}=\mathrm{D} \& \mathrm{Fil}$ $\mathrm{e}=$ sb0002Der.html\&Directory=session/2007D/Senate/ bills/billtext/html/. Visited website November 2007.

Florida Senate. 2007. Senate Joint Resolution 4-D, Enrolled. http://www.flsenate.gov/cgi-bin/ view_page.pl?Tab=session $\&$ Submenu $=1 \& \mathrm{FT}=\mathrm{D} \& \mathrm{Fil}$ $\mathrm{e}=$ sb0004Der.html\&Directory $=$ session/2007D/Senate/ bills/billtext/html/. Visited website November 2007.

Florida Senate. 2007. Senate Joint Resolution 6-D, Enrolled. http://www.flsenate.gov/session/ index.cfm?Mode $=$ Bills $\&$ SubMenu $=1 \& \mathrm{Tab}=$ session $\&$ BI_Mode=ViewBillInfo\&BillNum=0006\&Chamber= Senate $\&$ Year $=2007 D \&$ Title $=\% 2 \mathrm{D} \% 3 \mathrm{~EB}$ ill $\% 2520 \mathrm{Inf}$ o\%3AS\%25200006\%2D\%3ESession\%25202007D. Visited website November 2007. 
Florida House of Representatives. 2007. Senate

Property Tax Proposal - County By County

Analysis.

http://www.myfloridahouse.gov/FileStores/Web/

HouseContent/Approved/Announcements/Uploads/

Documents/

SENATE\%20County\%20by\%20County\%20v2.pdf.

Visited website November 2007.

Second Judicial Circuit Court. 2007. Final Summary Judgment and Cross Summary Judgment,

Case No. 37-2007-CA-1862. Second Judicial Circuit Court, Tallahassee, FL (September).

State of Florida. 2007. Florida Statutes, Chapter $192.001(11)(d)$.

http://www.flsenate.gov/Statutes/ index.cfm?App_mode=Display_Statute\&Search_Stri ng $=\& U R L=$ Ch0192/SEC001.HTM\&Title=-> 2007-

$>$ Ch0192->Section\%20001\#0192.001. Visited website November 2007.

State of Florida. 2007. Florida Statutes, Chapter 212.02 (19).

http://www.flsenate.gov/Statutes/ index.cfm?App_mode=Display_Statute $\&$ Search_Stri ng $=\& U R L=C h 0212 / S E C 02 . H T M \&$ Title $=->2007-$

$>$ Ch0212->Section\%2002\#0212.02. Visited website November 2007.

State of Florida. 2007. Florida Statutes, Chapter 218.67(1) Distribution for fiscally constrained counties. http://www.flsenate.gov/Statutes/ index.cfm?App_mode=Display_Statute\&Search_Stri $\mathrm{ng}=\& \mathrm{URL}=\mathrm{Ch} 0218 / \mathrm{SEC} 67 . \mathrm{HTM} \&$ Title $=->2007-$

>Ch0218->Section\%2067\#0218.67http:// www.flsenate.gov/Statutes/ index.cfm?App_mode=Display_Statute $\& U R L=C h 02$ $00 /$ titl0200.htm \&StatuteYear=2007\&Title $=\% 2 D \% 3 E 200$ 7\%2D\%3EChapter\%20200. Visited website November 2007. 